\title{
The use of brain CT Scan in craniocerebral trauma with Glasgow Coma Scale Scores of 13 - 15 in Dr. Cipto Mangunkusumo Hospital 1999-2001
}

Jofizal Jannis

\begin{abstract}
Abstrak
Penggunaan CT sken kepala pada pasien cedera kranioserebral ringan (CKR), saat ini masih kontroversial. Penelitian ini mempunyai tujuan mengetahui gejala klinis bermakna yang berhubungan dengan adanya gambaran CT sken abnormal pada pasien CKR dengan Skala Koma Glasgow (SKG) 13 - 15. Penelitian ini merupakan studi retrospektif dengan menganalisa catatan medik yang dibuat seragam pada penderita CKR dengan SKG 13 - 15 yang dirawat inap di ruang rawat Bagian Neurologi RSCM tahun 1999 - 2001. Hasil penelitian diperoleh data bahwa dari 1663 penderita dengan cedera kranioserebral, yang dirawat terdapat 1166 (70.1 \%) penderita CKR dengan SKG 13-15. Dari pasien CKR yang dirawat, hanya 271 (23.2\%) penderita yang menjalani pemeriksaan CT Sken. Kelainan CT Sken yang ditemukan diantaranya edema serebri (11.4\%), perdarahan intra parenkhimal (10.7\%), perdarahan epidural (16.2\%), perdarahan subdural (18.1\%), perdarahan subarakhnoid $(5.5 \%)$ dan campuran (13.8 \%). Analisis lanjutan menunjukkan bahwa gangguan saraf otak, amnesia, kehilangan kesadaran lebih dari 10 menit dan muntah bermakna secara statistik dengan kelainan CT Sken. Kombinasi keempat gejala klinis tersebut mempunyai sensitifitas yang tinggi (90 \%) dalam memprediksi adanya kelainan pada gambaran CT sken. Diharapkan hasil penelitian ini dapat menjadi patokan untuk menganjurkan CT Sken kepala pada penderita CKR dengan SKG (13 - 15). (Med J Indones 2004; 13: 156-60)
\end{abstract}

\begin{abstract}
There is still a controversy among the neurologists whether brain CT scan must be performed on the mild head trauma patients. This study was executed to find out the correlation between the brain CT scan image findings and its clinical impairment among the mild head trauma patients with Glasgow Coma Scale (GCS) score of 13 to 15. The study was a retrospective study by analyzing the uniform medical records of the head trauma patients hospitalized at the Neurology ward of Dr. Cipto Mangunkusumo Hospital within the period of 1999 to 2001. During that period 1,663 patients were hospitalized due to head trauma, and 1,166 of them (70.1\%) were suffered from mild head trauma patients with GCS score of 13-15. Among those with brain CT scan examinations (N: 271), the neurological abnormalities were found on 144 (53.1\%) of patients, consisted of cerebral edema (11,4\%), intracerebral hemorrhage (5.5\%), epidural hemorrhage (16.2\%), subdural hemorrhage (18.1\%), subarachnoid hemorrhage (5.5\%), and combination (13.8\%). The further analysis showed that cranial nerves disturbance, amnesia, loss of conciousness for more than 10 minutes, and vomiting are significantly correlated to the brain CT scan abnormality. Combination of the above four clinical signs and symptoms have sensitivity of $90 \%$ in predicting brain insults. This findings may be used as a simple set of clinical criteria for identifying mild head trauma patients who need undergo CT scan examination. (Med J Indones 2004; 13: 156-60)
\end{abstract}

Keywords: mild head injury, brain CT scan

Head injury is one of the leading cause of hospitalization at the Neurology ward and patients with Glasgow Coma Scale (GCS) scores of 13-15 are the most usual cases found in emergency and neurology ward. ${ }^{1-3}$ Previous study ${ }^{1}$ showed that $44 \%$ of patients with intracranial hemorrhage have scores of $13-15$ on GCS. This high percentage suggests that signs/symptoms

Departement of Neurology, Faculty of Medicine University of Indonesia/ Dr. Cipto Mangunkusumo National General Hospital, Jakarta, Indonesia found among head trauma patients must be considered to identify the abnormalities.

The question of which patients with head trauma should undergo scanning remained controversial since the introduction of computed tomography (CT scan) in the early 1970 s. $^{2}$ Brain CT scan is mandatory for moderate to severe head injury, while it is ruled necessary only in specific indication for mild head injury. Two large studies have suggested favorably for brain CT scan examinations among mild head injury patients. ${ }^{2,3}$ These studies showed that some clinical 
signs and symptoms can be used as predictors of the abnormality in brain CT scan with high degree of sensitivity and specificity. The use of these predictors as indication of brain CT scan in mild head trauma will propose for the more selective use of this technology, prevent the overuse of brain CT scan, and lead to large reduction in health care cost. Without selective guidelines there is a strong likelihood that use of CT for minor head injury will increase markedly in the next 5 years. ${ }^{3}$ Yet, these rules had not been validated in Indonesia.

Based on these reasons, this study was conducted on mild head trauma patients hospitalized in the Dokter Cipto Mangunkusumo Hospital Jakarta. The aims of this study is find the correlation between the clinical signs and symptoms and the brain CT scan findings, and to find the clinical signs and symptoms those can be use as a predictors for the abnormality in the brain CT scan examination.

\section{METHODS}

This study is a retrospective study performed based on the uniform medical records of head trauma patients, hospitalized at Neurology ward at Dokter Cipto Mangunkusumo Hospital, Jakarta within the period of 1999 to 2001. The inclusion criteria of respondents were the age more than 9 years old, suffered from head injury with GCS score of 13 - 15, and have performed brain CT Scan examination. The clinical signs and symptoms of the patients were collected, consisted of the onset, history of head impairment, amnesia, seizure, headache, vomiting, anisochoria of pupils, cranial nerves impairment, hematoma, motor disturbance, ear and nose bleeding. The correlation between the clinical signs and symptoms and the CT scan result was analyzed using SPSS 10.1.1 statistic program.

\section{RESULTS}

During the period of 1999 to 2001, as many as 1,663 head injury patients were hospitalized, and 1,166 $(70,1 \%)$ of them had GCS score of 13 to 15 . Out of 1,166 patients, only $271(23.2 \%)$ patients had brain CT scan examination and fulfilled the criteria. The age of patients was 9 to 79 years old, with the mean $28.75+/-14.01$ years old. Brain CT scan examination showed abnormal findings on 144 patients (53.31\%), consisted of cerebral edema, intracerebral, epidural, subdural and subarachnoid hemorrhage. See the table 1.

Table 1. Brain CT scan images of patients with GCS scores of 13-15

\begin{tabular}{lc}
\hline \multicolumn{1}{c}{ Radiology's Images } & $\mathrm{N}(\%)$ \\
\hline Normal & $127(46,9)$ \\
Cerebral Edema & $31(11,4)$ \\
Intracerebral Hemorrhage (ICH) & $29(10,7)$ \\
Epidural Hematoma (EDH) & $44(16,2)$ \\
Subdural Hematoma (SDH) & $25(18,1)$ \\
Subarachnoid Hematoma (SAH) & $15(5,5)$ \\
Combination & $27(13,8)$ \\
\hline \multicolumn{1}{c}{ Total } & $271(100)$ \\
\hline
\end{tabular}

The statistic analysis on the correlation between age and CT scan findings, showed that there was no correlation between the age of patients and CT scan abnormality $(\mathrm{p}=0.903)$. Table 2

Table 2. Age group and CT scan abnormalities

\begin{tabular}{cccc}
\hline Age & CT Scan (-) & CT Scan $(+)$ & N \\
\hline 9 - 29 years & 80 & 89 & 169 \\
30 - 44 years & 27 & 35 & 62 \\
45 - 60 years & 14 & 15 & 29 \\
$>60$ years & 6 & 5 & 11 \\
\hline Total & 127 & 144 & 271 \\
\hline
\end{tabular}

Symptoms and signs of the patients can be seen in the table 3. The statistical analysis on the correlation between the symptom and signs of the patients and the abnormal brain CT scan, showed that :

1. Onset of the disease, and motor disturbance had no correlation to the CT scan findings.

2. The correlation between the signs and symptoms and brain CT scan abnormality were found on amnesia $(\mathrm{p}<0.05)$, vomiting $(\mathrm{p}<0.001)$, loss of conciousness for more than 10 minutes, and cranial nerve disturbance $(\mathrm{p}<0.001)$.

3. Cranial nerve disturbance can be used as a predictor of brain CT scan abnormality with the sensitivity $13.2 \%$ and specificity $96.1 \%$. If either one of the findings was found, the sensitivity became $90 \%$ and specificity $37 \%$. See table 5 . 
Table 3. Relation between clinical findings of head injury with GCS scores of 13-15 patients and CT scan abnormalities

\begin{tabular}{|c|c|c|c|c|}
\hline Clinical Symptoms & $\mathrm{N}(\%)$ & CT Scan (-) & CT Scan (+) & $\mathrm{p}$ value \\
\hline $\begin{array}{l}\text { 1. Onset } \\
\begin{array}{ll}\text { 1.1. } & \text { Less than } 6 \text { hours } \\
\text { 1.2. } & 6-12 \text { hours } \\
\text { 1.3. } & 13-24 \text { hours } \\
\text { 1.4. } & \text { More than } 24 \text { hours }\end{array}\end{array}$ & $\begin{aligned} 135 & (49,8) \\
67 & (24,7) \\
22 & (7,1) \\
47 & (17,3)\end{aligned}$ & $\begin{aligned} 73 & (57,5) \\
27 & (21,3) \\
9 & (9,1) \\
18 & (14,2)\end{aligned}$ & $\begin{array}{l}62(45,1) \\
40(27,8) \\
13(9) \\
29(20,1)\end{array}$ & 0,128 \\
\hline $\begin{array}{l}\text { 2. Loss of Conciousness } \\
\text { 2.1. None or untill } 10 \text { minutes } \\
\text { 2.2. More than } 10 \text { minutes hours }\end{array}$ & $\begin{array}{l}140(51,7) \\
131(40,4)\end{array}$ & $\begin{array}{l}82(64,5) \\
45(35,4)\end{array}$ & $\begin{array}{l}58(40,2) \\
86(59,7)\end{array}$ & $\begin{array}{c}<0,001 \\
(\operatorname{LR} 1,625)\end{array}$ \\
\hline $\begin{array}{l}\text { 3. Amnesia } \\
\text { 3.1. None } \\
\text { 3.2. Amnesia }\end{array}$ & $\begin{array}{r}185(68,3) \\
86(31,7)\end{array}$ & $\begin{array}{r}100(78,7) \\
27(21,3)\end{array}$ & $\begin{array}{l}85(59) \\
59(41)\end{array}$ & $\begin{array}{c}<0,001 \\
(\operatorname{LR} 1,92)\end{array}$ \\
\hline $\begin{array}{l}\text { 4. Seizure } \\
\text { 4.1. } \text { Seizure }(-) \\
\text { 4.2. } \text { Seizure }(+)\end{array}$ & $\begin{array}{c}265(97,8) \\
\quad 6(2,2)\end{array}$ & $\begin{array}{c}125(98,4) \\
2(1,6)\end{array}$ & $\begin{array}{c}140(97,2) \\
4(2,8)\end{array}$ & 0,403 \\
\hline $\begin{array}{l}\text { 5. Headache } \\
\text { 5.1. Headache (-) } \\
\text { 5.2. Headache (+) }\end{array}$ & $\begin{array}{r}36(13,3) \\
235(86,7)\end{array}$ & $\begin{array}{r}23(18,1) \\
104(81,9)\end{array}$ & $\begin{array}{c}13(9) \\
131(91)\end{array}$ & $\begin{array}{c}0,022 \\
(\operatorname{LR} 1,11)\end{array}$ \\
\hline $\begin{array}{l}\text { 6. Vomiting } \\
\text { 6.1. Vomiting (-) } \\
\text { 6.2. Vomiting (+) }\end{array}$ & $\begin{array}{l}125(46,1) \\
146(53,9)\end{array}$ & $\begin{array}{l}74(58,3) \\
53(41,7)\end{array}$ & $\begin{array}{l}51(35,4) \\
93(64,6)\end{array}$ & $\begin{array}{c}<0,001 \\
(\operatorname{LR} 1,55)\end{array}$ \\
\hline $\begin{array}{l}\text { 7. Anisochor pupil } \\
\text { 7.1. Anisochor pupil (-) } \\
\text { 7.2. Anisochor pupil (+) }\end{array}$ & $\begin{array}{c}266(98,2) \\
5(1,8)\end{array}$ & $\begin{array}{c}126(99,2) \\
1(0,8)\end{array}$ & $\begin{array}{c}140(97,2) \\
2(2,8)\end{array}$ & 0,227 \\
\hline $\begin{array}{l}\text { 8. Cranial Nerves disturbances } \\
\text { 8.1. Cranial Nerves disturbances (- ) } \\
\text { 8.2. Cranial Nerves disturbances (+) }\end{array}$ & $\begin{array}{c}247(91,1) \\
24(8,9)\end{array}$ & $\begin{array}{c}122(96,1) \\
3(3,9)\end{array}$ & $\begin{array}{r}125(86,8) \\
19(13,2)\end{array}$ & $\begin{array}{c}0,007 \\
(\mathrm{LR}, 3,308)\end{array}$ \\
\hline $\begin{array}{ll}\text { 9. Hematoma } \\
\text { 9.1. None } \\
\text { 9.2. } \text { Subgaleal } \\
\text { 9.3. } \text { Eye glass } \\
\text { 9.4. } \text { Battle sign }\end{array}$ & $\begin{array}{r}231(85,2) \\
40(14,8)\end{array}$ & $\begin{array}{l}108(85,03) \\
19(14,07)\end{array}$ & $\begin{array}{r}123(85,4) \\
21(14,6)\end{array}$ & 0,930 \\
\hline $\begin{array}{l}\text { 10. Motor Disturbance } \\
\text { 10.1. Motor Disturbance (-) } \\
\text { 10.2. Motor Disturbance (+) }\end{array}$ & $\begin{array}{c}261(96,3) \\
10(3,7)\end{array}$ & $\begin{array}{c}125(98,4) \\
2(1,6)\end{array}$ & $\begin{array}{c}136(94,1) \\
8(5,6)\end{array}$ & 0,083 \\
\hline $\begin{array}{l}\text { 11. Ear and Nose bleeding } \\
\text { 11.1. Ear, Nose bleeding (-) } \\
\text { 11.2. Ear, Nose bleeding (+) }\end{array}$ & $\begin{array}{r}196(72,3) \\
75(27,7)\end{array}$ & $\begin{array}{l}95(74,8) \\
32(25,2)\end{array}$ & $\begin{array}{r}101(70,1) \\
43(29,1)\end{array}$ & 0,392 \\
\hline
\end{tabular}

Table 4. Relation between clinical findings and abnormal Brain CT Scan (multiple regression analysis)

\begin{tabular}{|c|c|c|c|c|}
\hline Clinical Findings & $\mathrm{N}$ & CT Scan (-) & CT Scan (+) & $\mathrm{p}$ value \\
\hline \multicolumn{5}{|l|}{ 1. Loss of consciousness } \\
\hline 1.1. None and until 10 minutes & 140 & 82 & 58 & \\
\hline 1.2. More than 10 minutes & 131 & 45 & 86 & 0,003 \\
\hline \multicolumn{5}{|l|}{ 2. Amnesia } \\
\hline 2.1. None & 185 & 100 & 85 & \\
\hline 2.2. Exist & 86 & 27 & 59 & 0,012 \\
\hline \multicolumn{5}{|l|}{ 3. Headache } \\
\hline 3.1. Headache (-) & 36 & 23 & 13 & \\
\hline 3.2. Headache $(+)$ & 235 & 104 & 131 & 0,265 \\
\hline \multicolumn{5}{|l|}{ 4. Vomiting } \\
\hline 4.1. Vomiting (-) & 125 & 74 & 51 & \\
\hline 4.2. Vomiting $(+)$ & 146 & 53 & 93 & 0,008 \\
\hline \multicolumn{5}{|l|}{ 5. Cranial Nerves Disturbance } \\
\hline 5.1. None & 247 & 122 & 125 & \\
\hline 5.2. Exist & 24 & 5 & 19 & 0,035 \\
\hline
\end{tabular}


Table 5. Sensitivity and specificity of the relation between combination of clinical findings and CT scan abnormality

\begin{tabular}{lcc}
\hline \multicolumn{1}{c}{ Clinical findings } & Sensitivities & Specificities \\
\hline 1. Cranial Nerves Disturbance & $13 \%$ & $96 \%$ \\
2. Cranial nerves disturbance, amnesia & $48 \%$ & $75 \%$ \\
3. Cranial nerves disturbance, amnesia, LOC >10 minutes & $76 \%$ & $53 \%$ \\
4. Cranial nerves disturbance, amnesia, LOC > 10 minutes, & $90 \%$ & $37 \%$ \\
$\quad$ vomiting & & \\
\hline
\end{tabular}

\section{DISCUSSION}

Generally, head injury patients with GCS 13-15 do not need brain CT scan examination since they are considered normal. In this study, as many as 1,663 head injury patients were hospitalized, and 1,166 $(70,1 \%)$ of them had GCS score of 13 to 15 . Out of 1,166 patients, only $271(23.2 \%)$ patients had brain CT scan examination without any specific criteria for its indication. The result of scan examination was abnormal in $53.1 \%$. Other studies ${ }^{4-7}$ reported various results. Jeret reported 759 patients, and 714 of them were scanned with $10 \%$ abnormal findings. ${ }^{4}$ While Dacey examined 68 out of 610 patients, found 34\% abnormalities. $^{8} \quad$ Stein and Ross reported $18 \%$ abnormalities among 658 patients, with $5 \%$ of them required surgery. ${ }^{5}$ This difference might be caused by different sample size and CT scanned indication criteria. In Cipto Mangunkusumo hospital, scan was ruled necessary in mild head injury patient if clinical condition worsen, lucid interval suspicion, and lateralization signs (anisochor pupil or hemiparesis). ${ }^{9}$ In United States, patients were scanned selectively depending upon clinical indications, while in Italia scan was ruled necessary if there was fracture in plain skull $\mathrm{x}$-ray. ${ }^{2,3}$ The indications of scan were more directives in England and Spain., ${ }^{2,3}$ They applied scan if there were skull fracture, focal neurology deficit and history of changes in level of consciousness.

Many other studies were done to identify hemorrhage risk in mild head injury or patients with GCS 13-15. The result of those studies varied between 0 to $26 \%$. To identify clinical impairments, this study looked at the signs and symptoms, and then correlated them with CT scan image. Sensitivity and specificity of the relationship of the signs or symptoms and scan abnormality were then tested to determine the criteria to apply CT scan.

From sensitivity and specificity test, cranial nerves disturbances had low sensitivity to predict abnormal CT scan. However when accompanied by amnesia,
LOC more than 10 minutes and vomiting, the sensitivity was high $(90 \%)$. It was different to the result of Canadian CT Head Rule by Verbeck et al ${ }^{3}$ which stated that there were five high risk factors to be considered for CT scan which were inability to attain scores of 15 on GCS within 2 hours after accident, open skull fracture suspicion, cranial base fracture, vomiting more than 2 episode, and age more than 65 years. If there were all of the findings, the sensitivity was $100 \%$ for CT scan rule. The study determined that moderate risk factors including amnesia for more than 30 minutes in dangerous injury (e.g. fall, motorcycle accident) had sensitivity of $98.4 \%$. Although there were differences between the two risk factors, factor that contributed for high sensitivity could be determined clinically. Jeret et $\mathrm{al}^{4}$ examined 712 patients with scores of 15 on GCS that had amnesia and decrease level of consciousness history. The results were 4 factors that had significant statistical correlation with CT scan abnormality, including old age, white people, cranial base fracture sign, pedestrian hit by car/motorcycle, and falling patient.

Meanwhile Hydel ${ }^{2}$ calculated clinical sensitivity of headache, vomiting, age more than 60 years, alcohol / drug intoxication, short memory deficit, fracture above the clavicle, and seizure. The combination of those signs had sensitivity of $100 \%$ to predict abnormal scan. Beside it, examination of the symptoms that appeared after trauma such as cranial nerves and motor disturbance had strong relation with abnormal CT scan image that whenever existed CT scan should be ruled. Similar to studies done in UK and Spain, ${ }^{3}$ CT scan was recommended for patients with GCS scores of $13-15$ if they had skull fracture, focal neurology deficit, and mental status disturbance.

\section{CONCLUSIONS}

1. Diagnosis of mild head injury cannot based on Glasgow Coma Scale alone, but also the signs and symptoms related to it. 
2. More than half of head injury hospitalized patients with GCS scores of $13-15$, had abnormal CT scan $(53.1 \%)$.

3. The result of this study may be used as a simple set of clinical criteria for identifying patients with scores of $13-15$ on GCS who should undergo CT scanning. Our results suggest that such patients can be identified by the presence of one or more the following findings which are cranial nerves disturbance, amnesia, LOC more than 10 minutes, and vomiting.

4. Since our study is based upon retrospective data, it is suggested that there should be multicenter and prospective cohort study regarding this issue.

\section{REFERENCES}

1. Turana $\mathrm{Y}$, Jannis J. Intracranial hemorrhage in craniocerebral injury in Cipto Mangunkusumo hospital between 1998-2000. Medika 2002; 28:12-6.

2. Hydel JM, Preston CA, Mills TJ. Indication for computed tomography in patients with minor head injury. $\mathrm{N}$ Eng $\mathbf{J}$ Med 2000; 343:100-5.
3. Stiell IG, Wells GA, Vandemheen K, Clement C, Lesink $\mathrm{H}$, et al.. Canadian $\mathrm{CT}$ head rule for patient with minor head injury. Lancet 2001; 357:1391-6.

4. Jeret JS, Mandell M, Anziska B, Lipitz M, Vilcens AP, et al. Clinical predictor of abnormality disclosed by computed tomography after mild head trauma. Neurosurgery 1993; 32: 9 - 15

5. Stein SC, Ross SE. The value of computed tomography scans in patients with low risk head injury. Neurosurgery 1990; 26: 638 - 40

6. Rimel RW, Giordani B, Barth JT. Disability cause by minor head injury. Neurosurgery 1982; 9:221-8.

7. Feurman T, Wackym PA, Gade GF. Value of skull radiography, head computed tomography scanning and admission. In cases of minor head injury. Neurosurgery 1988; 22:449-53.

8. Dacey RB, Alves WM, Rimel RW. Neurosurgical complication after apparently minor head injury. J Neurosurg 1985; 62:194-9.

9. Markam S. Trauma of the central nervous system : mechanism, pathology, and pathophysiology of head trauma.( Indonesia ). In : Markam S ( ed). Guidelines of Neurology $2^{\text {nd }}$ ed. Jakarta : Binarupa Aksara ; 1992.p. 74-92. 